\title{
Obituary
}

\section{A Tribute to the Late Dr. Sulayman Shehu Nyang}

\author{
Altaf Hussain
}

It was Fall 1998, here I was, at Howard University, the mecca. Walking the historic grounds of the campus, I was tracing the footsteps of luminaries and intellectual giants, scientists and activists, who gave birth to inventions and social movements, and who were of African, Afro-Caribbean and African American descent, among others. Before enrolling in the doctoral program in the School of Social Work, I had known of Dr. Nyang but only interacted with him in passing at a few programs. All over the world, for nearly four decades, among Muslims, Howard University was synonymous with Dr. Sulayman Shehu Nyang. This proud and brilliant son of Africa was known for his Gambian roots, his prolific scholarship, his contagious smile, his wit, his insights, his at once profound brilliance and his down to earth demeanor, and his steady hand as Chair of the African Studies department at Howard University. I can count with rare exception the number of times I introduced myself as being a doctoral student, an administrator, a faculty member and now a department chair at Howard University, and the almost instant reaction among Muslims - Oh yeah, Dr. Nyang is at Howard.

I have never met anyone like him. That was my first reaction when I finally got to spend time with Dr. Nyang on the campus of Howard Univer-

Altaf Husain serves as Associate Professor and Chair of the Community, Administration and Policy Practice Concentration at the School of Social Work, Howard University. He also serves as Vice President of the Yaqeen Institute for Islamic Research and as a member of the Board of Directors of the Muslim Students Association of the US and Canada (MSA National). 
sity. He would ultimately honor me by serving as a member of my dissertation committee. During that period, our meetings were scheduled, and we spent time reviewing the draft of each chapter. However, most cherished among my memories are the unplanned meetings, the spontaneous encounters on campus, when it seemed both of us were in a hurry and yet, neither of us wanted to part company.

Over the years, he took a keen interest in everything I was doing as a student in the School of Social Work, as vice president and then president of the Muslim Students Association of the US and Canada, as a newly married man, as a father to be, as an invited lecturer, and as an aspiring student of knowledge. Dr. Nyang would often say, we are blessed with opportunities in America to make a difference, to tell our story, and we must do so with excellence. He had this uncanny ability to strike up a conversation as if there had been no break since the last time we had met or spoken. He never missed a beat. He remembered everything in both the intellectual and mundane domains. He could take even the most banal of topics and redirect the conversation to include historical references and roots, to connect the past to the present, to project out to the future, and all the while to treat you, the conversation partner, as an equal. His tone was never condescending, nor did he ever exaggerate. He drew deeply from his wealth of knowledge and shared unselfishly. If I expressed anxiety about classes or the dissertation, or later on about my role as the executive assistant for academic affairs in the Office of the Provost, or as a faculty member in the School of Social Work, he would smile, listen intently, and then, in a most brilliant manner, offer words of comfort, help me to contextualize my feelings, share concrete strategies and next steps, and perhaps most importantly for any mentor, empower and encourage me so that I literally felt I could conquer the world and that nothing was impossible.

\section{A Generous Scholar, Par Excellence}

One could spend a lifetime trying to grasp the depth and breadth of Dr. Nyang's scholarly contributions broadly to the field of African Studies, to the understanding of the rise, decline and ultimately failure of the nation-state, and the history and development of the Muslim community in the United States. It is this last area with which I became most familiar among his contributions. Dr. Nyang, along with Dr. Zahid Bukhari, were blessed with the opportunity to co-lead a project at Georgetown University, titled "Muslims in the American Public Square," or MAPS. Among the final 
products was a volume co-edited by Dr. Nyang, Dr. Bukhari and their colleagues, Dr. Mumtaz Ahmad and Dr. John Esposito, Muslims' Place in the American Public Square: Hopes, Fears, and Aspirations.

I had the good fortune to be close by at Howard University so I attended various meetings and convenings, as a part of MAPS, of leaders of the Muslim community from around the United States. The discussions were candid, difficult, often contentious and yet, I was never anxious because, Dr. Nyang was present. He was blessed by Allah with a phenomenal ability to inject timely and proportionate doses of humor to lessen the tension in the room. To the African Americans, he was one of them. A native of Gambia, a scholar of Islam in Africa and in the United States, he commanded their respect and love. To the immigrants, he was one of them. An international student, a recipient of a doctoral degree from the University of Virginia, a scholar who had lived the immigrant experience in the United States, he commanded their respect and love. To the Shi'a community, he was one of them. To the Sufi community, he was one of them. To the Sunnis, he was one of them. He was truly blessed and embraced the role of bridge builder between the African Americans, the immigrants, and Muslims of diverse backgrounds.

His scholarship, research and public lectures span over nearly five decades. Over that period, he helped to instill a sense of pride in Muslims by bringing to light the tremendous contributions of Muslims in Africa, of Muslims in the United States, and ultimately in his projections of the trajectory of future generations of Muslims in the United States and around the world. During various lectures I attended, it was always heartwarming to see how animated he would become and how genuinely he wanted his audience to know about the potential Muslims had to lead humanity. His scholarship, whether in the form of peer-reviewed journal articles or books or essays in periodicals, is imbued with that same determination and pride. Towards the last decade of his life, it became clear that he developed an unstoppable passion for preservation, archiving and meaning-making about the history and development of the Muslim community in the United States. When news of his death spread on social media, a common theme emerged as people from varied professional backgrounds shared memories of their interactions with him: document and tell your story, you have a story to tell! 


\section{Final Thoughts}

In the weeks and months following the terrorist attacks of September 11, 2001, it seemed there was a program about Islam and Muslims in the United States on every day of the week. The demand was overwhelming, and the supply of people qualified to meet that demand was short. And so, the burden was shouldered by a few, Dr. Nyang, among them. Indeed, we owe him a collective debt of gratitude. The clarity and confidence with which Dr. Nyang responded to very tough questions about Islam, in part, lifted the veil of fog and dampened the rage among those who were convinced that Islam was an inherently violent religion, and that Muslims were hell bent on destroying the "West".

Without once complaining, Dr. Nyang, it seemed, did it all: lectures on college campuses from coast to coast, panels of interfaith leaders in various houses of worship, roundtables in thinktanks, half day and all-day seminars, small and large conferences, and radio and television interviews. So grueling was the schedule, so taxing were the flights and car rides, so emotionally, mentally and physically draining was the routine, he fell ill. It was during this time that he reached out on two occasions to request that I speak in his place. I recall resisting and quite candidly letting him know that the organizers of these events were expecting the Dr. Nyang and not one of his students. And this is precisely why I grew so fond of him: he said without hesitation that one of his goals had been to keep nurturing and investing in the growth and development of a new generation of leaders and scholars. Simply put, he was convinced that my time had come and that I was ready now to carry the baton. Talking about the next generation is cliché, it is overused. Often the people saying they care about paving the way for that coming generation have no intention of moving aside, or of sharing the limelight, or of passing the baton. Dr. Nyang, who was so fond of witty expressions and often shared their origins, was the real deal. Harboring no resentment nor regret, he was visibly moved with love and affection upon seeing his students excel.

One speaking engagement which he requested that I cover was slightly less intimidating because it was at a local church in DC. He said a handful of people would be my audience for an intimate conversation. There were tough questions, but overall I developed an appreciation for the work he had been doing in traveling and speaking at these engagements. I came to value the importance of direct interaction with people who were our neighbors and co-workers, and who, almost literally overnight it seemed, 
had come to view Muslims with deep suspicion. His voice rang through my head and I visualized his encouraging smile, as I answered each question. We laughed about it later because of how intellectually demanding these outings were and how it was totally acceptable to smile and say I'm sorry, I don't know the answer to that but I will take your contact information and get back to you.

The more daunting assignment was the one in which I filled in when he was to serve as a co-panelist, in front of a live audience, for the taping of a special for National Geographic. Don Belt had completed editing his book The World of Islam, and Don, Dr. Yvonne Haddad (another scholarly giant), Richard W. Murphy (a former US Assistant Secretary of State and current director of Middle East Studies for the Council on Foreign Relations), and I were to have a conversation about Islam in America. I was petrified. But again, Dr. Nyang, in his calm manner, provided much needed encouragement. He said essentially, this is your life, you have grown up here, so just talk about your experiences. Dr. Haddad was equally encouraging and by all accounts, we had a wonderful evening. I had been introduced to the world so to speak and it was all due to the mentoring and generosity of Dr. Nyang who afforded me the opportunity to speak.

Although he lived a productive and full life for another fifteen years after that period, it was clear that his health never fully recovered. It is not at all an exaggeration to say that he is among those whom Allah preserved and protected because of how urgently his expertise was needed. He documented his near-death experience in painstaking detail in an essay entitled, "What Near Death Taught Me About Life." He would often say afterwards, that he had to do even more now that Allah had extended his time on earth. On March 16, 2016, Dr. Nyang suffered a severe stroke which left him in a coma. Doctors had little hope that he would survive. I visited him in the hospital a few times, and it was heartbreaking to see this loving soul in that condition. I recall vividly the phone call from his wife, Mrs. Eucharia Mbachu-I need help, the doctors are insisting that we take him off life support. I spoke to her at length, comforted her, and we agreed that this was no ordinary man-he is a fighter and he will indeed pull through with our prayers. I prayed intently and everyone who knew Dr. Nyang also prayed. He recovered from the coma-he survived! It was truly a miracle that even his doctors could neither comprehend nor explain. Regrettably, in the months that followed, Dr. Nyang never fully recovered from complications from the 2016 stroke. On November 12, 2018, Dr. Sulayman Nyang returned to his 
Creator. Even in his death he was a uniting force as hundreds of people of all races and nationalities, young and old, from near and from far, came to bid him farewell on November 14 at the Islamic Society of the Washington Area in Silver Spring, Maryland. I was honored to read aloud a resolution from Howard University, acknowledging his decades of contributions to the University and indeed, the world.

So often we hear the tradition of the Prophet Muhammad recited during funerals, about the three things a person leaves behind after death. There is absolutely no doubt that Dr. Nyang left behind knowledge that is, has been, and inshäallāh will continue to be of benefit for generations to come. We accept that he is no more with us, we mourn his loss, and we are fully convinced that indeed he was a true servant of Allah, endowed with an unparalleled spirit of generosity and of tremendous wit and wisdom. Most importantly, he truly served humanity as a scholar, seeking neither thanks nor reward. He lived seeking only the Countenance of Allah. 